\title{
Sekizinci Sınıf Öğrencilerinin Cebirsel Düşünme Becerilerinin Matematik Odaklı Epistemolojik İnançlar Bağlamında Açıklanması
}

\section{Explanation of Eighth-Grade Students' Algebraic Thinking Skills in the Context of Mathematics-Oriented Epistemological Beliefs}

\author{
Deniz KAYA*
}

Received: 31 July 2018

Research Article

Accepted: 12 March 2019

\begin{abstract}
In this study, the skills of algebraic thinking of eighth-grade students were considered in the context of mathematics-oriented epistemological beliefs. A total of 162 students studying at the eighth grade level of a public school in Izmir city center participated in the study. A mathematics-oriented epistemological beliefs scale was used to determine students' epistemological beliefs, and an algebraic thinking tool was used to determine algebraic thinking skills. The responses of the students to the questions aiming to determine the algebraic thinking skills were analysis through rubrics and statistical analysis were carried out to determine the relations. Quantitative data analysis was also supported by qualitative findings from students' response papers. According to the results of the analysis, significant correlations between the mathematics-oriented epistemological beliefs and the algebraic thinking abilities were found to be high, moderate and weak. According to multiple regressions, beliefs about effort, talent, and the existence of a single truth account for $65 \%$ of the total variance associated with algebraic thinking. According to qualitative findings, it was determined that students with high beliefs related to the effort were better algebraic thinking. At the end of the study, it was suggested that students should have good algebraic thinking skills by presenting learning experiences that are mathematics-oriented epistemological beliefs.
\end{abstract}

Keywords: algebraic thinking, eighth-grade, epistemological beliefs, mathematics.

ÖZ: Araştırmada sekizinci sınıf öğrencilerinin cebirsel düşünme becerileri matematik odaklı epistemolojik inançlar bağlamında ele alınmıştır. Çalışmaya İzmir şehir merkezindeki bir devlet okulunun sekizinci sınıf düzeyinde öğrenim gören toplam 162 öğrenci katılmıştır. Öğrencilerin epistemolojik inançlarını belirlemek için matematik odaklı epistemolojik inanç ölçeği, cebirsel düşünme becerilerini belirlemek için cebirsel düşünme aracı kullanılmıştır. Öğrencilerin cebirsel düşünme becerilerini belirlemeyi amaçlayan sorulara verdiği yanıtlar rubrik aracılığıyla analiz edilmiş, söz konusu ilişkileri belirlemek için istatistiksel analizler gerçekleştirilmiştir. Nicel veri analizleri öğrencilerin cevap kâğıtlarından ulaşılan nitel bulgularla da desteklenmiştir. Analiz sonuçlarına göre, öğrencilerin matematik odaklı epistemolojik inançları ile cebirsel düşünme becerileri arasında pozitif yönde yüksek, orta ve zayıf olmak üzere anlamlı ilişkiler belirlenmiştir. Çoklu regresyona göre, öğrenmenin çabaya, yeteneğe ve tek bir doğrunun var olduğuna yönelik inançlar cebirsel düşünme becerisine ilişkin toplam varyansın \%65'ini açıklamıştır. Nitel bulgulara göre, çabaya bağlı inancı yüksek olan öğrencilerin cebirsel düşünme düzeylerinin de yüksek olduğu belirlenmiştir. Çalışma sonunda, öğrencilerin iyi bir cebir düşünme becerisine sahip olmalarında matematik odaklı epistemolojik inançlara uygun öğrenme yaşantılarının sunulması öneri olarak sunulmuştur.

Anahtar kelimeler: cebirsel düşünme, epistemolojik inançlar, matematik, sekizinci sınıf.

*Corresponding Author: Dr., Ministry of National Education, İzmir, Turkey, denizkaya38@gmail.com, https://orcid.org/0000-0002-7804-1772

Citation Information

Kaya, D. (2019). Sekizinci sınıf öğrencilerinin cebirsel düşünme becerilerinin matematik odaklı epistemolojik inançlar bağlamında açıklanması. Kuramsal Eğitimbilim Dergisi [Journal of Theoretical Educational Science], 12(2), 576-600. 


\section{Giriş}

Cebir öğrenme alanı günümüz bilgi toplumunun vazgeçilmezleri arasındadır. Sahip olduğu güçlü dinamik yapısı, kendine has özellikleri, birçok alanı besleyen fonksiyonu ve yaklaşık 4000 yıllık geçmişi ile matematiğin gözde uygulama alanıdır (Usiskin, 1995). Cebir; denklemleri çözmek, fonksiyonel ilişkileri analiz etmek, ifadeler ile ilişkilerden oluşan temsil sistemlerinin yapısını belirlemek için sembollerle ve genişletilmiş sayılarla ilgilenen bir öğrenme alanıdır (Lew, 2004). Kieran (1992) cebiri harfleri kullanarak nicelikleri ve sayıları temsil eden bir araç olarak tanımlamaktadır. Bu düşünceyi destekleyen Romberg ve Spence (1995) cebirin "dünyayı anlamlandırma, tahmin edemediğiniz veya ölçemediğiniz şeyler hakkında çıkarımlar yapmak için bir araç olduğunu" vurgulamıştır (s. 186). Bu güçlü söylemler elbette cebir öğretiminin önemini tam olarak ifade etmese de günlük yaşam içinde cebire her geçen günden daha fazla ihtiyaç duyulduğu aşikârdır. Öyle ki çok sayıdaki öğretim programlarında cebir, matematiksel düşüncenin ana iskeletini oluşturmaktadır (MEB, 2018; NAEP, 2015; NCTM, 2014). NCTM'e (2006) göre, öğrenciler cebirin sembolik tarafı ile cebire ait kavramları iyi bilmek zorundadır. Çünkü cebir; bir dil, bir düşünce aracı, problemleri çözmek için etkili bir uygulama ve her şeyden önemlisi bir okul dersidir (Dede \& Argün, 2003). Bu bakımdan cebir, öğrenciler için kritik bir öğrenme alanıdır (Kaput, 2002). Usiskin (1995) cebiri genelleştirilmiş bir aritmetik olarak nitelendirse de gerçek ve varsayımsal kalıpları tanımlamak için sembolik bir dil, problemleri çözmek ve ilişkileri incelemek için matematiksel yapılar olarak tanımlamaktadır. Cebirin bu güçlü yönü sadece yüksek seviyedeki matematiksel derslere erişime izin vermekle kalmaz aynı zamanda potansiyel başarının da önemli bir bileşenini oluşturur (Kaput, 1998). Bu bakımdan cebir, bireylerin iyi birer matematik okuryazarı olmalarının yanı sıra ileri düzey matematiksel becerileri edinmelerinde gerekli araci rolleri çoktan üstlenmiştir. Özellikle öğrencilerin mantıksal çıkarımlar yapmasına ve soyut düşünebilme yetilerini geliştirmesine kapı aralaması bu rollerin başında yer alır (Stacey \& MacGregor, 1999). Nitekim bu duruma dikkat çeken Erbaş, Çetinkaya ve Ersoy’a (2009) göre cebir, soyut düşünce yapısıyla diğer bilim dalları ve matematiğin alt alanları arasında kavramsal ve kuramsal bir köprü ve dil görevi üstlenmektedir. Tüm bu anlatımlar 1şığında cebir yapısının içeriği aşağıda özetlenmeye çalışılmıştır.

Şekil 1. Cebir Yapısı

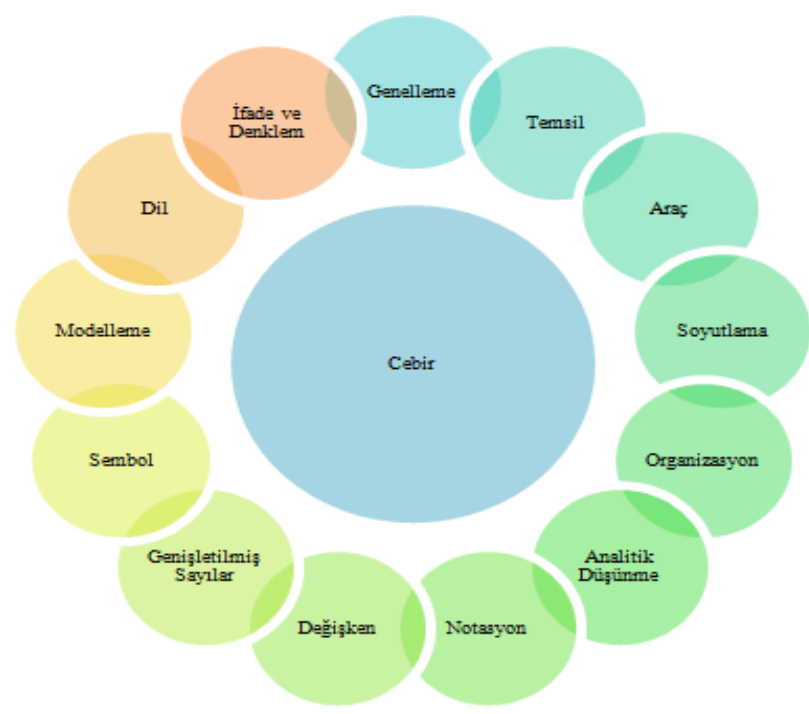


Cebire yönelik çok sayıdaki modern yaklaşımlar bir arada düşünüldüğünde genellemeden modellemeye, analitik düşünmeden soyutlamaya, organizasyondan ifade, değişken ve denklemlere kadar birçok alanlarda kullanımlarının olduğu görülmektedir (Erbaş ve diğer., 2009; Kaput, 1998, 2008; Kieran, 1992; Lew, 2004; NCTM, 2006; Romberg \& Spence, 1995; Stacey \& MacGregor, 1999; Usiskin, 1995).

Cebir, günümüz matematik öğretim programında varlığını hissettirdiği andan itibaren öğrenciler için bir meydan okuma alanı haline dönüşmüştür. $\mathrm{Bu}$ durumun birçok nedeni olmakla birlikte bilinmeyen sayılar için harf kullanımı (ör. x, y, z vb.) ile değişkenlerin varlığı temel gerekçeler arasında gösterilebilir (Chaurasia, 2016). Bunun dışında değişkenlerin farklı kullanımını bilememe (Dede, 2004), cebirsel kavramları anlamada zorlanma (Dede \& Argün, 2003), denklem çözümünde güçlükler yaşama (Van Amerom, 2003), eşitlik ve değişken kavramlarında sorunlar hissetme (Ersoy \& Erbaş, 2005), aritmetikten cebire geçişte sıkıntılar çekme (Akkan \& Baki, 2016) ile harfleri yorumlamada hatalar yapma (Kieran, 1992; MacGregor \& Stacey, 1997) diğer gerekçeler arasında gösterilebilir. Alanda yer alan kayda değer çok sayıdaki gelişmelere rağmen etkili bir cebir öğretimi/öğrenimi konusunda yeterli ilerlemelerin kaydedilmeği görülmektedir. $\mathrm{Bu}$ durumun en güçlü kanıtı uluslararası değerlendirme kuruluşlarının yayınlamış olduğu raporlardır (OECD, 2016; TIMSS, 2016). Örneğin Uluslararas1 Eğitim Başarılarını Değerlendirme Kuruluşu tarafından yayınlanan 2015 yılı raporunda katılımcı 39 ülkenin cebir performansı dikkate alınmış, aralarında Türkiye, Gürcistan, Norveç, Malezya, Tayland ve İtalya'nın da yer aldığı 24 ülkenin cebir performansı ortalamanın [ortalama cebir puanı: 483] gerisinde kalmıştır (TIMSS, 2016). Bu nedenle öğrencilerin cebir performanslarını etkileyen değişkenlerin araştırılması önemli bir konu olarak karşımıza çıkmaktadır. Özellikle ülkemizde matematik performansında dördüncü sınıftan sekizinci sınıfa düşük düzeyde performans gösteren öğrencilerle üst düzeyde performans gösteren öğrenciler arasında öğrenme farkının artması (TEDMEM, 2018) bu gerekçeyi daha belirgin kılmaktadır. Diğer yandan cebirsel düşünme ile epistemolojik inanç kavramları kuramsal çerçevede ayrıntılı bir şekilde ele alınmıştır.

\section{Kuramsal Çerçeve}

Son yıllarda araştırmacıların, eğitim politikacıların, öğretim programı yapıcıların ve araştırma kuruluşların sıklıkla dile getirdiği söylemler arasında cebirsel düşünmenin öğrencilerin matematiksel deneyimlerinin merkezinde yer alması gerektiği görüşü ön plana çıkmaktadır (NAEP, 2015; NCTM, 2014). Cebirsel düşünme, cebir teriminin sahip olduğundan daha geniş ve daha kapsamlı bir anlama sahiptir (Çelik, 2007). Cebirsel düşünme aktivitesi bir zihinsel alışkanlık olmasının yanında matematiksel içerik hakkında yararlı düşünme biçimleriyle yakından ilişkili çeşitli çağrışımları da barındırmaktadır (Cuoco, Goldenberg, \& Mark, 1996). Bu nedenle düşünme, özellikle de cebirsel düşünme soyutlamayı anlamak için önemli bir araçtır (Russell, 1999). İlgili alanyazında cebirsel düşünme için farklı anlamlar yüklenmiş çok sayıda ve farklı türde tanımlamalar yapıldığı dikkat çekmektedir. Kieran ve Chalouh'a (1993) göre, cebirsel düşünme sembol ve işlemleri aritmetik olarak anlamlandırma işidir. Vance (1998) cebirsel düşünmeyi genellemeleri, değişkenleri ve soyutlamaları içeren akıl yürütme yolu şeklinde tanımlamıştır. Driscoll (1999) değişkenler arasındaki ilişkilerin açıklığa kavuşturulmasını destekleyen niceliksel durumlar hakkında düşünme biçimi olarak yorumlamıştır. Slavit (1999) cebirsel düşünmenin sayısal ve aritmetik anlayışla 
geliştiğini ifade etmiştir. Kaput (2008) ise cebirsel düşünmenin genellemeleri giderek artan bir şekilde geleneksel sembol sistemlerde ifade etme ile sembolik formlarla muhakeme yapma şeklinde iki temel yönü üzerine vurgu yapmıştır. Benzer şekilde, Carpenter ve Levi (2000) cebirsel düşünmenin bu güçlü yönlerine dikkat çekerek; genellemeler yapmada, matematiksel fikirleri temsil etmede aynı zamanda problemleri çözmede kullanılan semboller olarak tanımlamıştır. Bu durum NCTM'e (2006) göre, matematiksel modeller kullanarak nicel ilişkileri temsil ve analiz etmek, fonksiyonları anlamak ve çeşitli durumlardaki değişimi fark etmektir. Sonuç olarak, bir çeşit zihinsel aktivite olan cebirsel düşünme; sembollere anlamlar yükleyerek cebirsel ilişkiler arasında bağ kurmayı, cebirsel ilişkilerin içerisinde yer alan somut-yarı somut ve soyut kavramları betimlemeyi ve muhakeme etme yoluyla sonuca ulaşabilmeyi temsil etmektedir (Kaya, 2015). Bu bağlamda, cebirsel düşünme için fonksiyonlar, modelleme ve genelleştirilmiş aritmetik döngüsünde temsil edilen ortak bileşenlerin ürünüdür denilebilir. Süreç, daha anlaşı1ır olması için aşağıdaki şekilde özetlenmeye çalışılmıştır.

Şekil 2. Cebirsel Düşünme Çerçevesi

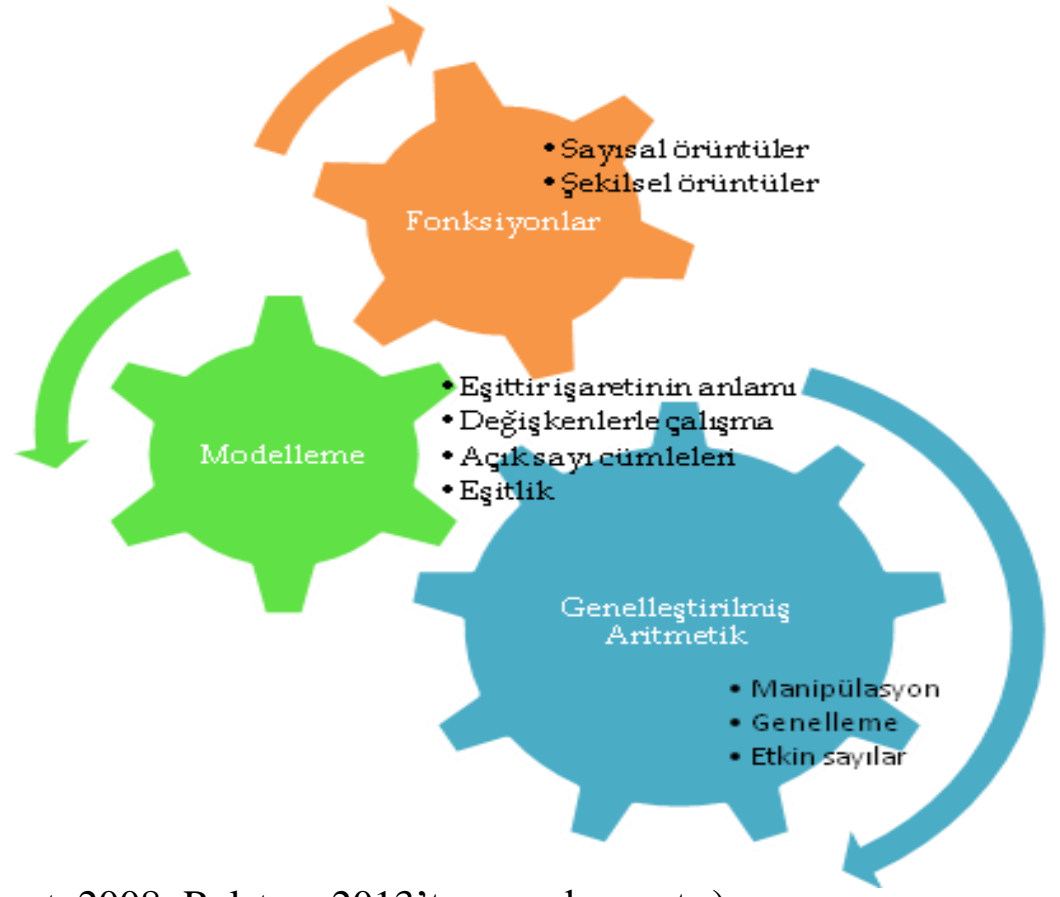

(Kaput, 2008; Ralston, 2013’ten uyarlanmıştır)

Eğitim politikalarının en önemli sacayaklarından birisi de öğrencilerin sahip oldukları inanç değerleridir. Son on y1llık süreçte özellikle eğitimciler tarafından bireylerin inanç ve epistemolojik gelişimlerine yönelik artan bir ilgi söz konusudur. Bu durumun en önemli gerekçeleri ise bireysel faktörlerin başarı üzerindeki rolleri ile kuramsal çalışma alanlarının destekleyici etkileridir (Schommer, 1990). Epistemolojik inançlar; öznel inançları kapsamakla birlikte bilginin doğasına, bilmenin ve öğrenmenin nasıl gerçekleştiğine yönelik çabaların ürünüdür (Hofer \& Pintrich, 1997; Schommer, 1990). Bu bağlamda epistemolojik inançlar sadece bilgi birikimleriyle değil, bilginin edinilmesi ve kullanım alanlarını içeren öğrenme yetenekleriyle ilgili inançları da içermektedir (Deryakulu, 2004a). Burada cevabı aranan soru ise doğru bilginin kaynağı, ölçütü, sınırı ve kapsamıdır (Çüçen, 2013). Dolayısıyla bireylerin cevap aradığı sorular onun öğrenme anlayışını, farklılığını ve inançlarını da etkiler. Nitekim epistemolojik 
inançların öğrenme-öğretme üzerinde doğrudan ya da dolaylı etkilerinin olduğu bilinmektedir (Deryakulu, 2004b; Hofer, 2000). Bu söz dizimi beraberinde inançların çabanın, anlamanın ve başarının yordayıcısı olduğu varsayımlarını da tetiklemiştir. Alanyazında yer verilen birçok çalışma bulgusu da epistemolojik inançların öğrenme sürecinde önemli bir değişken olduğunu göstermektedir (Chan, 2003; Deryakulu, 2004b, Deryakulu \& Büyüköztürk, 2002; Hofer, 2000; Schommer-Aikins, Duell, \& Hutter, 2005; Schommer, 1990, 1998). Çünkü bireylerin epistemolojik anlayış1 onun gerçekliğe dayalı olarak bilginin nasıl üretildiğine yönelik bakış açılarını da etkilemektedir (Tezci \& Uysal, 2004). Eğitim penceresinden bakıldığında bu inançlar, yalnızca öğrencilerin değil, tüm eğitim paydaşlarının davranış ve düşüncelerine dolayısıyla öğretim faaliyetlerine de yansır. Bu bakımdan epistemolojik inançlar ile öğrenme yaklaşımları ve bilişsel aktiviteler yakından ilişskilidir (Chan, 2003). Tüm bu anlatımlar 1şığında, epistemolojik inançlar için bireylerin zihinsel aktivitelerini etkileyen yargılamaların toplamıdır denilebilir. Bu bakımdan yürütülen çalışmada epistemolojik inançların birbirinden bağımsız çoklu yapısı tercih edilmiştir. Çalışmanın temel felsefi yaklaşımı Schommer (1990) tarafından dile getirilen bilgilerin birbirinden bağımsız parça ve boyutlardan oluştuğu kuramsal anlayışa dayanmaktadır. Çünkü epistemolojik inançlar doğası gereği tek bir boyut yerine daha fazla boyuttan oluşan bir ölçümle değerlendirilmelidir (Schommer \& Dunnell, 1997).

Alanyazın incelendiğinde, Yıldırır ve Çirkinoğlu-Şekercioğlu (2018) tarafından 56 öğrenci ile yapılan görüşmede, öğrencilerin çoğunluğu öğrenmenin çabaya bağl1 olduğunu, yeteneğin çabayla gelişebileceğini ve bilginin kesinlikle değişebileceği fikrini paylaşmışlardır. Hacıömeroğlu (2011) tarafından 204 öğrenci ile yürütülen çalışmada, epistemolojik inanç ile problem çözme arasında zayıf ve orta düzey ilişki belirlenmiştir. Öğrenmenin çabaya ve yeteneğe bağlı olduğu inanç değişkenleri matematiksel problem çözmenin önemli yordayıcıları olmuştur. Schommer ve diğer., (1997) tarafindan 69 öğrenciyle yürütülen boylamsal çalışmada, öğrencilerin birinci sınıftan son sınıfa doğru ilerledikçe öğrenmenin zaman içinde geliştiğine inandıkları, daha yüksek performansa ve gelişmiş epistemolojik inançlara sahip oldukları belirlenmiştir. Başka bir çalışma, Erdamar ve Alpan (2015) tarafindan 149 öğrenci ile yürütülmüştür. Çalışma sonunda, birinci sınıfta öğrenmenin çabaya bağlı olduğuna inananlar kaçıngan, yeteneğe bağlı olduğuna inananlar değerlendiren, kendine güvenli ve planlı, tek bir doğruya inananlar planlı olarak belirlenmiştir. Bunların yanı sıra son sınıfta öğrenmenin çabaya bağlı olduğuna inananlar değerlendiren, yeteneğe bağlı olduğuna inananlar düşünen, değerlendiren, kendine güvenli ve planlı, tek bir doğruya bağlı olduğuna inananlar ise aceleci, kaçıngan, değerlendiren, kendine güvenli ve planlı olarak rapor edilmiştir. Aksan ve Sözer (2007) tarafından 208 öğrenci ile yürütülen çalışmada, epistemolojik inanç ile problem çözme becerileri arasında anlamlı bir ilişki belirlenmiştir. Öğrenmenin çabaya bağlı olduğuna inanan öğrencilerin problem çözme sürecinde değerlendirici bir yaklaşım izledikleri belirtilmiştir. Aynı zamanda tek bir doğrunun var olduğu inancına yakın olmayan öğrenciler problem çözme sürecinde ortaya çıkan sonuç ile bekledikleri sonucu karşılaştırma eğilimi gösterdikleri rapor edilmiştir. ÖzkanHıdıroğlu ve Hıdıroğlu (2016) tarafından yürütülen çalışma sonucunda, epistemolojik inanç ile matematiksel modelleme yaklaşımları arasında zayıf ilişki olduğu ve epistemolojik inançların matematiksel modelleme yaklaşımlarını zayıf ve orta düzeyde yordadığı tespit edilmiştir. Qian ve Alvermann (2000) tarafından yürütülen çalışmanın 
bulguları, gelişmiş epistemolojik inançlara sahip öğrencilerin yüksek performans; gelişmemiş epistemolojik inançlara sahip öğrencilerin düşük performans gösterdiklerine işaret etmektedir. Aydemir, Aydemir ve Boz (2013) tarafından 356 lise öğrencisi ile yürütülen çalışmada, öğrencilerin bilginin zamanla değişebileceği boyutunda gelişmiş, bilginin kaynağı/değişmezliği boyutunda ise daha az gelişmiş epistemolojik inançlara sahip olduğu gözlenmiştir. Öngen (2003) tarafından 155 lisans öğrencisi ile yürütülen çalışmada, öğrencilerin öğrenmenin çabaya ve yeteneğe bağlı olduğu inanç boyutlarında gelişmiş epistemolojik inanca sahip oldukları ancak öğrencilerin tek bir doğrunun var olduğuna yönelik inancının diğer iki boyuttaki kadar gelişmediği görülmüştür. Yılmaz (2007) tarafından 47 lise öğrenci ile yürütülen çalışmada, öğrencilerin bekledikleri gibi sade veya alışılmış formatta sonucu olmayan problemlerin cevabında şüpheye düştüğü görülmüştür. Ayrıca bu inançların, yeterli bilgi ve beceriye sahip olsalar da, öğrencilerin problem çözümlerindeki performanslarına negatif etki ettiği gözlemlenmiştir

Alanyazın irdelendiğinde, çalışmaların çoğunluğunda epistemolojik inançların başarı, sınıf, problem çözme ve görüşlere dayalı olarak ele alındığı dikkat çekmektedir (Aksan \& Sözer, 2007; Erdamar \& Alpan, 2015; Haciömeroğlu, 2011; Öngen, 2003; Qian \& Alvermann, 2000; Schommer ve diğer., 1997; Y1lmaz, 2007). Özellikle cebirsel düşünme ve epistemolojik inanç arasındaki ilişkinin incelendiği bir çalışmaya alanyazında rastlanılmamıştır. Dolayısıyla bireylerin kararlarını ve davranışlarını etkileyen (Hofer \& Pintrich, 1997) bu inançların cebirsel düşünme üzerinde tartışılması, araştırmaya değer bir konu olarak karşımıza çıkmaktadır. Araştırmanın bir diğer güçlü yönü ise bu alanda kısıtlı çalışmaların olmasından dolayı benzer çalışmalara ışık tutacak olmasıdır. Bu bakımdan çalışmanın alana önemli katkılar sunması beklenmektedir. Tüm bu anlatımlar 1şığında çalışmanın temel amacı, sekizinci sınıf öğrencilerinin cebirsel düşünme becerilerini matematik odaklı epistemolojik inançlar bağlamında açıklamaya çalışmaktır.

\section{Yöntem}

\section{Araştırma Deseni}

Sekizinci sınıf öğrencilerinin cebirsel düşünme becerileri ile matematik odaklı epistemolojik inançları arasındaki ilişkinin belirlenmesi amaçlandığından araştırmada ilişkisel araştırma deseninden yararlanılmıştır. İlişkisel araştırma olarak da adlandırılan korelasyonel araştırmada değişkenlere herhangi bir müdahale yapılmaksızın iki veya daha fazla değişken arasındaki ilişkinin birlikteliğinden yararlanılır (Fraenkel \& Wallen, 2009). Bunun yanı sıra çalışmada nicel verileri desteklemek amacıyla öğrencilerin cebirsel düşünme becerilerinin değerlendirildiği cevaplara da yer verilerek araştırmaya nitel bir boyut da kazandırılmıştır.

\section{Çalışma Grubu}

Araştırmanın çalışma grubunu, 2017-2018 öğretim yılında, İzmir şehir merkezindeki bir devlet ortaokulunun sekizinci sınıfında öğrenim gören 162 öğrenci oluşturmaktadır. Araştırmada gönüllü olarak yer alan öğrencilerin \%51.2'si $(n=83) \mathrm{k1z}$, \%48.8'i (n=79) erkektir. Çalışmaya toplamda 165 öğrenci katılmış ancak bir öğrenci ismini belirtmediğinden, iki öğrenci de ölçme aracı uygulamasının çözümünü yarıda bıraktığından çalışmaya dâhil edilmemiştir. Çalışma grubunun oluşturulmasında uygun örnekleme yöntemi temel alınmıştır. Bu yöntem zaman, para ve işgücü kaybını azaltmayı amaç edinen bir yöntemdir ve araştırmacılar kolay ulaşılabilir aynı zamanda 
uygulama yapılabilir birimlerden seçilmesine yönelik seçkisiz olmayan uygun bir durum veya örnek üzerinde çalışır (Büyüköztürk, Çakmak, Akgün, Karadeniz, \& Demirel, 2014). Bu sayede kolay, pratik aynı zamanda ekonomik bir uygulama yolu tercih edilmiştir.

\section{Veri Toplama Araci}

Araştırmanın verileri, güvenirliği ve geçerliği test edilmiş matematik odaklı epistemolojik inanç ölçeği ile araştırmacı tarafından geliştirilen ve cebirsel düşünme becerisini değerlendirmeyi amaçlayan ölçme aracı kullanılarak toplanmıştır. Çalışmada kullanılan ölçek ve ölçme aracına ait ayrıntılı bilgi aşağıda sunulmuştur.

Matematik Odaklı Epistemolojik Ínanç Ölçeği (MOEIO). Ölçek, öğrencilerin matematiğe yönelik epistemolojik inançlarını ölçmeye olanak tanıması amacıyla tasarlanmıştır (İlhan \& Çetin, 2013). Ölçeğin hazırlanmasındaki temel felsefi yaklaşımı farklı kültürde geliştirilen inanç ölçeklerinden ziyade Türk kültürüne uygun genel ve alan odaklı inanç ölçeklerinden yola çıkılmış olmasıdır. MOEİÖ geliştirilirken Schommer (1990) tarafından geliştirilen, Deryakulu ve Büyüköztürk (2002) tarafından Türkçeye uyarlanan epistemolojik inanç ölçeği dikkate alınmıştır. Ölçek; Öğrenmenin Çabaya Bağlı Olduğuna İnanç (ÖÇBOİ), Öğrenmenin Yeteneğe Bağlı Olduğuna İnanç (ÖYBOİ) ile Tek Bir Doğrunun Var Olduğuna İnanç (TBDVOİ) olmak üzere üç boyuttan oluşmaktadır. Ölçeğin ÖÇBOİ ve ÖYBOİ boyutlarında 10, TBDVOİ boyutunda 7 madde bulunmaktadır. Ölçeğin hesaplanan Cronbach's alpha iç tutarlılık katsayısı sırasıyla ÖÇBOİ için .84, ÖYBOİ için .81 ve TBDVOİ için .71 olarak belirtilmiştir. Ölçeğin üç faktörlü yapısı için yapılan doğrulayıcı faktör analizi sonucunda elde edilen uyum indeksleri $\mathrm{x}^{2} / \mathrm{sd}=2.38$, RMSEA=.06, NNFI=.90, IFI=.90, CFI=.90, SRMR=.08 olarak belirlenmiştir. 5'li Likert tipindeki ölçekte yer alan ifadeler için (1) Kesinlikle Katılmıyorum, (2) Katılmıyorum, (3) Kararsızım, (4) Katılıyorum, (5) Kesinlikle Katıliyorum şeklinde bir derecelendirme kullanılmıştır. MOEİÖ’nin alt boyutlarındaki örnek maddeler Tablo 1'de sunulmuştur.

Tablo 1

\section{MOEİ̈’nin Boyutlarına Göre Örnek Maddeleri}

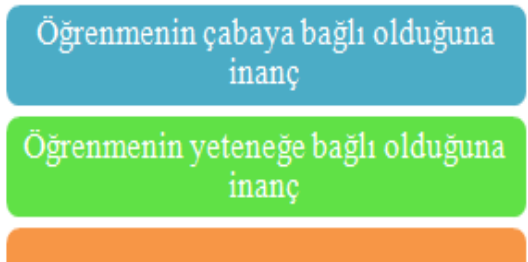

Tek bir doğrunun var olduğuna inanç
- Matematik alanındaki en başarılli insanlar en fazla çaba harcayan insanlardir

- Matematik alanındaki zor konuları, yalnızca matematik alanında yetenekli olan insanlar ögrenebilir.

-Matematik alanındaki her konu hakkında yalnızca tek bir doğru vardır.

Cebirsel düşünme aracı. Çalışmada öğrencilerin cebirsel düşünme becerilerini belirlemek için ortaokul sekizinci sınıf ders kitabı, ulusal merkezi sınav soruları, öğretmen ile matematik öğretim programı desteğiyle hazırlanan yedi soruluk açık uçlu problemler kullanılmıştır. Cebir öğrenme alanını içeren problemlerin hazırlanmasında uzman görüşü alınmıştır. Hazırlanan soruların ölçme amacına uygun olup olmadığı ve ölçülmek istenen alanı temsil edip etmediği uzman görüşüne göre saptanır (Karasar, 2013). Bu doğrultuda, hazırlanan sorulara ilişkin cebir öğrenme alanında uzman bir 
araştırmacıdan, her soru ile ilgili görüş alınmıştır. Daha sonra üç farklı ortaokul matematik öğretmeninden soruların öğrencilerin seviyeleri ile kazanımlara uygunluğu noktasında görüşler alınmıştır. Akademisyen ve öğretmenlerin görüşleri alındıktan sonra pilot uygulamaya geçilmiştir. Pilot uygulamanın temel nedeni öğrencilerin sorularda yaşadığı zorluklar ile araştırmacı kaynaklı hataların en aza indirilme çabasıdır. $\mathrm{Bu}$ bağlamda, pilot uygulama gerçekleştirilerek gerekli düzeltmeler ve düzenlemelere gidilmiştir. Örneğin bir soru cümlesi (6. soru) farklı çıkarımlara neden olduğu ve birden fazla olası cevaplar içerdiği, bir diğer soru cümlesi (7. soru) öğrenci seviyesinin oldukça altında ve kazanımlara uygunluğu tartışmalı olduğu gerekçeleriyle ölçme aracından çıkartılmıştır. Nihayetinde dokuz soruluk ölçme aracı yedi soruya indirgenmiştir. Bu aşamadan sonra uygulama öğrencileri dişında yer alan ve sekizinci sınıf düzeyinde 15 kişilik bir çalışma grubu ile ikinci bir pilot uygulama yapılmış, öğrencilerin anlamakta güçlük çektiği kısımlar belirlenerek gerekli düzenlemeler yapılmıştır. Örneğin bir soru cümlesi öğrenciler tarafından farklı anlamlar yüklendiği için tekrar düzenlenmiş, başka bir soru cümlesi de öğrencilere oldukça karmaşık ve zor geldiği için sadeleştirilmiştir. Bu sayede hazırlanan sorulara ait dil, seviye, uygunluk ve içerik geçerliliği sağlanmıştır. Bunların yanı sıra ölçme aracının Cronbach Alpha ölçüm güvenirlik katsayısı ise .93 $(n=162)$ olarak hesaplanmıştır. Güvenirlik hesaplaması yapılırken rubrik değerlendirme ölçeğine göre, öğrencilerin her bir soru için verdikleri ölçümlenmiş cevapları dikkate alınmıştır. Kazanımlara uygun olarak hazırlanmış örnek cebirsel düşünme problemi aşağıda sunulmuştur.

Örnek soru cümlesi (4. Soru). Bir mermerci kolay bir şekilde ölçüm yapmak için çırağından $100 \mathrm{~cm}$ uzunluğunda bir metal şerit yaptırmasını istiyor. Ancak çırak yanlışlıkla $80 \mathrm{~cm}$ uzunluğunda bir metal parçası yaptırıor. Bu mermerci, boyutları gerçekte 4 metreye 8 metre olan mermeri çırağın yaptırdığı metal şerit ile ölçüyor ve yaptığı bu ölçüme göre, fiyatını hesaplayıp müşterisine satıyor. Mermerin metrekare fiyatı 5 TL olduğuna göre, mermerci müşterisinden fazladan kaç TL almıştır? Çözümünüzü ayrıntılı bir şekilde yapınız.

Öğrencilere soruları çözmeleri için toplamda bir saat süre verilmiştir. Pilot çalışma ile test edilen bu süre, uygulama öğrencileri için de yeterli görülmüştür. Pilot uygulamada öğrencilerden beklenen; soruyu anlamak, sorunun amacina uygun bir plan yapmak, bildiklerini kâğıda organize bir şekilde aktarmak, sorunun çözümünü değişik biçimlerde (grafik, tablo, resim, şekil vb.) ifade etmek, matematiksel işlemleri etkili bir şekilde kullanmak ve uygun bir strateji doğrultusunda açık, net ve anlaşılır bir dil kullanmaktır. Öğrenciler soruları matematik öğretmenleri gözetiminde çözmüştür. Ders öğretmenleri herhangi bir müdahalede bulunmaksızın öğrencilerin ne düşündüklerini ayrıntılı bir şekilde yazmaları konusunda açıklamalarda bulunmuşlardır.

\section{Verilerin Analizi}

Yürütülen çalışmada, matematik odaklı epistemolojik inançların alt boyutları ile cebirsel düşünme becerisi arasındaki ilişki Pearson momentler çarpım korelâsyon tekniği ile hesaplanmıştır. Bunun yanında matematik odaklı epistemolojik inançların cebirsel düşünme becerisi üzerindeki etkisini incelemek için hem her bir boyut için basit doğrusal regresyon analizi hem de tüm boyutlar için çoklu doğrusal regresyon analizi gerçekleştirilmiştir. Ancak analizleri gerçekleştirmek için birtakım varsayımların karşılanması önemlidir. Öncelikle veri setinin normal dağılım gösterip göstermediğini incelemek için çarpıklık ve basıklık değerleri incelenmiştir. Çarpıklık ve basıklık katsayılarının kendi standart hatalarına bölünmesi ile hesaplanan çarpıklık ve basıklık 
indekslerinin .19 ile .37 arasında değiştiği belirlenmiştir. Bu katsayıların, \pm 2 sınırları içinde 0'a yakın olması normal dağılımın varlığına kanıt olarak değerlendirilmektedir (Tabachnick \& Fidell, 2013). Bunun yanında örneklem veri kümesinin büyüklügüne bağlı olarak Kolmogorov-Smirnov (kişi sayısı 50'den fazla) normallik testi de anlamlı ( $p>.05)$ bulunmamıştır. Bu bakımdan verilerin normal dağılım gösterdiği aynı zamanda mevcut verilerin dağılımı ile normal olasılık dağılımı arasında fark olmadığı söylenebilir (Can, 2016). Diğer yandan çok değişkenli analizler öncesinde; uç değerlerin etkileri, sayıltılar arasındaki uyum, çoklu bağlantı problemi varsayımlarına bakılması gerekir (Çokluk, Şekercioğlu \& Büyüköztürk, 2014). Normal dağılım varsayımının karşılanıp karşılanmadığı mahalanobis uzaklık değerleri hesaplanarak incelenebilir (Büyüköztürk, 2017). Veri setine ait mahalanobis uzaklık değerleri ki-kare değeri ile karşılaştırılarak incelenmiş, doğrusallık ve normallik varsayımını güçleştiren herhangi bir değere rastlanılmamıştır. Ayrıca veri setinin doğrusallık varsayımı bağımlı ve bağımsız değişkenlerin toplu serpinti matrisi grafiği incelerek test edilmiştir. Regresyon analizinin bir diğer varsayımı yordayıcı değişkenler arasında çoklu bağlantı probleminin bulunmamasıdır. Çoklu bağlantı problemi araştırmanın bağımsız değişkenleri arasında güçlü ilişkilerin ( $r>.90$ ve üzeri) bulunmasıdır (Çokluk ve diğer., 2014). Alanyazında çoklu bağıntı problemini test etmek için genellikle varyans artış faktörlerinin (VIF), tolerans değerlerinin (TV), durum indeksinin (CI) ve bağımsız değişkenler arasındaki korelasyonların hesaplanması önerilmektedir (Büyüköztürk, 2017; Çokluk ve diğer., 2014). Buna göre, eğer VIF değerleri 10'a eşit ve daha büyükse (VIF $\geq 10)$, TV değerleri .10 eşit veya daha küçükse $(\mathrm{TV} \leq .10)$ ve $\mathrm{CI}$ değeri 30 'a eşit ve daha büyükse $(\mathrm{CI} \geq 30)$ çoklu bağıntı probleminin olduğuna işaret etmektedir (Çokluk ve diğer., 2014). Bu çalışmada bağımsız değişkenler arasındaki en yüksek korelasyon .79'dur. Değişkenlerin VIF değerleri 1.95-2.08; CI değerleri .00-12.26 ve TV değerleri .49-.83 arasında değişmektedir. Sonuç olarak, elde edilen VIF, CI ve TV değerleri dikkate alındığında bağımsız değişkenler arasında çoklu bağlantı probleminin olmadığı söylenebilir.

Araştırmanın diğer değişkeni olan cebirsel düşünme aracının puanlandırılması Marzano'nun (2000) geliştirmiş olduğu aşamalı puan ölçeğinden uyarlanan rubrik yardımıyla yapılmıştır. Aşamalı puan ölçeği, öğrencilerin sorulara vermiş olduğu yanıtların karşılaştırmalı olarak analiz edilmesinde kullanılmıştır. Öğrenciler, yöneltilen soruların çözümünde soru hakkındaki düşüncelerini de ayrıntılı bir şekilde kâğıda aktarmıştır. Her bir soru için en yüksek 4, en düşük 0 puan olmak üzere beş farklı [0-12-3-4] şekilde kodlanmıştır. Bundan dolayı öğrencilerin verdikleri cevaplar her bir soru için ayrı ayrı değerlendirmeye tabi tutulmuştur. Cebirsel düşünme aracının değerlendirilmesinde kullanılan rubrik aşağıda sunulmuştur.

Şekil 3. Cebirsel Düşünme Aracı Değerlendirme Rubriği

- Öğrenci cebirsel problemin çözümünde en etkili yolu seçer ve bunun olası çözüm yolları içerisinde neden en etkilisi olduğunu net bir şekilde açıklar.

- Öğrenci bir engelin veya zorluğun üstesinden gelmede en etkili çözüm yolunu seçer ve bunun olas1 çözüm yolları içerisinde neden en etkilisi olduğunu tam olarak açıklayamaz.

- Öğrenci bir engelin veya zorluğun üstesinden gelmede doğru bir çözüm yolu seçer ama bu en etkili olan değildir. Ögrencinin vermiş olduğu cevap çözüm sürecini kısmen de olsa gösterir niteliktedir.

- Öğrencinin seçmiş olduğu çözüm yolu engelin veya zorluğun üstesinden gelebilecek nitelikte değildir.

- Öğrenci hiçbir yargıda bulunmaz ya da bulunduğu yarg1 soru cümlesi ile ilgili değildir. 
Cebirsel düşünme aracındaki soruların puanlanmasındaki güvenirliği sağlamak amacıyla araştırmacı ve alan uzmanı tarafından rastgele seçilen on öğrencinin cevap kâğıtları birbirinden bağımsız olarak değerlendirilmiştir. Değerlendirmeler Miles ve Huberman'ın (1994) uyum yüzdesine göre karşılaştırıldığında tüm sorularda \%90'nın üzerinde uyum yüzdesine ulaşılmıştır. Tavşancıl ve Aslan'a (2001) göre puanlayıcılar aras1 uyum yüzdesinin \%70'den daha yüksek olması gerekmektedir. Bu bakımdan veri analizi güvenirliğinin sağlandığı söylenebilir.

\section{Bulgular}

$\mathrm{Bu}$ bölümde, araştırmanın amacına uygun olarak önce veri setinden elde edilen istatistiksel değer daha sonra matematik odaklı epistemolojik inançlar bağlamında öğrencilerin çözümlerine yer verilmiştir. Verilerin analizinden elde edilen bulgular, matematik odaklı epistemolojik inanç ölçeği ile cebirsel düşünme aracından elde edilen sayısal puanlardan oluşmaktadır. Çalışmada nicel verilerin yanı sıra öğrencilerin cevap kâğıtlarından elde edilen nitel bulgulara da yer verilmiştir.

Tablo 2

MOEİ İle Cebirsel Düşünme Becerisi Arasındaki İlişki

\begin{tabular}{lccccccc}
\hline MOEI & $N$ & Ort. & $S s$ & Toplam & $r$ & $p$ & İlişki düzeyi \\
\hline $\begin{array}{l}\text { Öğrenmenin çabaya } \\
\text { bağlı inanç }\end{array}$ & 162 & 2.56 & 1.10 & 415.50 & .792 & $.000^{*}$ & $\begin{array}{c}\text { Yüksek düzey } \\
\text { ilişki }\end{array}$ \\
$\begin{array}{l}\text { Öğrenmenin yeteneğe } \\
\text { bağlı inanç }\end{array}$ & 162 & 2.13 & .49 & 345.50 & .267 & $.000 *$ & $\begin{array}{c}\text { Zayıf düzey } \\
\text { ilişki }\end{array}$ \\
$\begin{array}{l}\text { Tek bir doğrunun var } \\
\text { olduğuna inanç }\end{array}$ & 162 & 2.47 & .87 & 401.29 & .657 & $.000 *$ & $\begin{array}{c}\text { Orta düzey } \\
\text { ilişki }\end{array}$ \\
\hline \multicolumn{1}{c}{$* p<.001$} & & & & & & &
\end{tabular}

Tablo 2 incelendiğinde, istatistiksel açıdan öğrencilerin matematik odaklı öğrenmenin çabaya bağlı olduğu inançları ile cebirsel düşünme becerileri arasında pozitif yönde, yüksek düzey anlamlı bir ilişski $(r=.792 ; p<.001)$ belirlenmiştir. Diğer yandan öğrenmenin yeteneğe bağlı olduğu inançları ile cebirsel düşünme becerileri arasında pozitif yönde, zayıf ve anlamlı bir ilişki $(r=.267 ; p<.001)$ varken tek bir doğrunun var olduğu inançları ile cebirsel düşünme becerileri arasında pozitif yönde orta düzey anlamlı bir ilişki $(r=.657 ; p<.001)$ tespit edilmiştir. Matematik odaklı epistemolojik inançlarının her bir boyutunun cebirsel düşünme becerisini anlamlı olarak yordayıp yormadığını belirlemek amacıyla yapılan basit doğrusal regresyon analiz sonuçları aşağıda sunulmuştur. 
Tablo 3

MOEİ'nin Cebirsel Düşünme Becerisini Yordamasına Ait Basit Doğrusal Regresyon

\begin{tabular}{|c|c|c|c|c|c|c|c|c|}
\hline Değişkenler & $R$ & $R^{2}$ & Düzeltilmiş $\mathrm{R}^{2}$ & $B$ & Std. Hata & $\beta$ & $t$ & $F$ \\
\hline $\begin{array}{l}\text { Öğrenmenin çabaya } \\
\text { bağlı inanç }\end{array}$ & .792 & .628 & .625 & .679 & .041 & .792 & $16.42 *$ & 269.72 \\
\hline $\begin{array}{l}\text { Öğrenmenin yeteneğe } \\
\text { bağlı inanç }\end{array}$ & .267 & .071 & .066 & .512 & .146 & .267 & $3.51 * *$ & 12.31 \\
\hline $\begin{array}{l}\text { Tek bir doğrunun var } \\
\text { olduğuna inanç }\end{array}$ & .657 & .432 & .428 & .715 & .065 & .657 & $11.02 *$ & 121.51 \\
\hline
\end{tabular}

Tablo 3'e göre, matematik odaklı epistemolojik inançlar içerisinden öğrenmenin çabaya bağlı olduğu inanç $\left(F_{(1-160)}=269.72 ; t=16.42 ; p<.000\right)$, öğrenmenin yeteneğe bağl1 olduğu inanç $\left(F_{(1-160)}=12.31 ; t=3.51 ; p<.05\right)$ ile tek bir doğrunun var olduğuna yönelik inanç $\left(F_{(1-160)}=121.51 ; t=11.02 ; p<.000\right)$ boyutları anlamlı birer yordayıc1 olmuştur. Değişkenler tek başına incelendiğinde, matematik odaklı öğrenmenin çabaya bağlı olduğu inanç boyutu cebirsel düşünme becerisi üzerindeki değişimin \%62'sini $\left(R=.792, R^{2}=.628\right)$ açıklamaktadır. Diğer değişkenlerden öğrenmenin yeteneğe bağlı olduğu inanç cebirsel düşünme becerisi üzerindeki değişimin \%7'sini $(R=.267$, $\left.R^{2}=.071\right)$, tek bir doğrunun var olduğu inanç cebirsel düşünme becerisi üzerindeki değişimin yaklaşık \%43'ünü $\left(R=.657, R^{2}=.432\right)$ açıklamaktadır. Yordayıcı değişkenlere ilişkin regresyon katsayıları incelendiğinde, öğrenmenin çabaya bağlı olduğu değişkeninin en yüksek ( $\beta=.792)$, öğrenmenin yeteneğe bağl1 olduğu değişkeninin ise en düşük $(\beta=.267)$ regresyon katsayısına sahip olduğu belirlenmiştir. Bunun yanı sıra matematik odaklı epistemolojik inançların cebirsel düşünme becerisini yordama derecesine ilişkin çoklu regresyon analizi yapılmıştır. Matematik odaklı epistemolojik inanç boyutlarının cebirsel düşünme becerisini yordama gücü aşağıda sunulmuştur.

Tablo 4

MOEİnin Cebirsel Düşünme Becerisini Yordamasına Ait Çoklu Doğrusal Regresyon

\begin{tabular}{lcccccc}
\hline Değişkenler & $B$ & Std. Hata & $\beta$ & $t$ & İkili r & Kismi r \\
\hline Sabit & -.252 & .205 & - & -1.23 & - & - \\
$\begin{array}{l}\text { Öğrenmenin çabaya } \\
\text { bağlı inanç }\end{array}$ & .562 & .056 & .656 & $10.01 *$ & .792 & .623 \\
$\begin{array}{l}\text { Öğrenmenin yeteneğe } \\
\text { bağlı inanç }\end{array}$ & -.098 & .098 & -.051 & -.99 & .267 & -.079 \\
$\begin{array}{l}\text { Tek bir doğrunun var } \\
\text { olduğuna inanç }\end{array}$ & .242 & .072 & .222 & $3.34 * *$ & .657 & .257 \\
& & & & & & \\
\hline
\end{tabular}

$* p<.001 ; * * p<.05$

Öğrencilerin cebirsel düşünme becerisi üzerinde etkisi olduğu düşünülen matematik odaklı epistemolojik inançların yordandığı çoklu regresyon analizi 
sonucunda, öğrenmenin çabaya ve yeteneğe bağlı olduğu ile tek bir doğrunun var olduğuna yönelik inançlar birlikte ele alındığında cebirsel düşünme becerisine ilişkin toplam varyansın \%65'ini açıklamaktadır. Regresyon eşitliğindeki parametre değerleri dikkate alındığında, yordayıcı değişkenlerinin [standardize edilmiş katsayı $(\beta)$ ] cebirsel düşünme becerisi üzerindeki göreli önem sırasının; öğrenmenin çabaya bağlı olduğuna inanç $(\beta=.656 ; t=10.01 ; p<.000)$, tek bir doğrunun var olduğuna bağlı inanç $(\beta=.222$; $t=3.34 ; p<.05)$ ve öğrenmenin yeteneğe bağlı olduğuna inanç $(\beta=-.051 ; t=-.99 ; p>.05)$ olduğu görülmektedir (Tablo 4). Regresyon eşitliğinde yer alan " $B$ " katsayısı cebirsel düşünme becerisindeki değişimi ifade eder. Örneğin öğrenmenin çabaya bağlı olduğu inanç boyutundaki bir standart sapma artış cebirsel düşünme puanında .562 artışa neden olmaktadır. Benzer şekilde, öğrenmenin yeteneğe bağlı inanç boyutunda -.098 düşüşe, tek bir doğrunun var olduğu inanç boyutunda ise .242 artışa neden olmaktadır. Bütün değişkenler birlikte değerlendirildiğinde, öğrenmenin çabaya bağlı olduğu inanç ile tek bir doğrunun var olduğuna yönelik inançların cebirsel düşünme becerisinin anlamlı birer yordayıcısı, öğrenmenin yeteneğe bağlı olduğu inancin ise anlamlı bir yordayıcısı olmadığı belirlenmiştir.

Çalışmada, nicel verilerin yanında öğrencilerin cebirsel düşünme aracına yönelik cevaplarını içeren çözümleri; öğrenmenin çabaya, yeteneğe ve tek bir doğrunun var olduğuna bağlı inançları bağlamında incelenmiş ve cevap kağıtlarından birtakım kesitler aşağıda sunulmuştur.

\section{Öğrencilerin Cebirsel Düşünme Aracına Yönelik Cevapları}

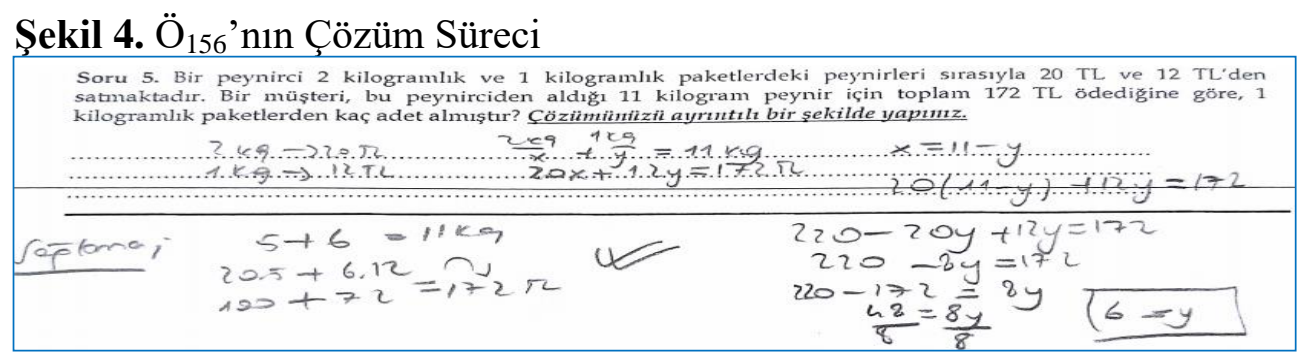

[Öğrenmenin çabaya bağlı inanç toplam puanı: 45]

Matematik odaklı epistemolojik inançlar içerisinden çabaya bağlı öğrenme inanç puanı yüksek olan Ö$_{156}$ 'nın soru çözümü incelendiğinde, çözüm için amaca uygun bir plan yaptığı göze çarpmaktadır. Bu doğrultuda çözüm için uygun bir denklem oluşturmuş ve matematiksel işlemleri etkili bir şekilde gerçekleştirmiştir. Olası çözüm yolları içerisinden etkili bir çözüm yolu seçmiş ve uygulamıştır. Üstelik soru çözümü sonunda sağlama işlemi ile yaptığı çözümün doğruluğundan emin olmuştur. $\mathrm{Bu}$ kapsamda öğrenci çabasının cebirsel bir dil ile şekillendiği söylenebilir.

Şekil 5. Ö 144 'ün Çözüm Süreci

\begin{tabular}{|c|c|}
\hline & 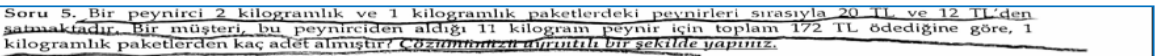 \\
\hline & 2kg+2oth \\
\hline $\begin{array}{r}20 \\
20 \\
20 \\
20 \\
20 \\
20 \\
\frac{20}{122}\end{array}$ & 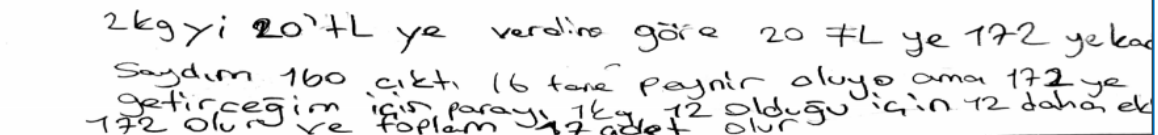 \\
\hline
\end{tabular}

[Öğrenmenin çabaya bağlı inanç toplam puanı: 21] 
Matematik odaklı epistemolojik inançlar içerisinden çabaya bağlı öğrenme inanç puanı düşük olan Ö$_{144}$ 'ün soru çözümü incelendiğinde, öncelikle çözüm için amaca uygun bir plan yapmadığı görülmektedir. Ayrıca seçmiş olduğu çözüm yolunun engelin üstesinden gelebilecek nitelikte olmadığı söylenebilir. Bu yüzden çözüm için uygun bir denklem kuramamış dolayısıyla cebirsel işlemleri etkili şekilde gerçekleştirememiştir. $\mathrm{Bu}$ kapsamda öğrenci çabasının cebirsel bir dil için yeterli olmadığı ve bu durumunda inanç çabalarını olumsuz etkilediği söylenebilir.

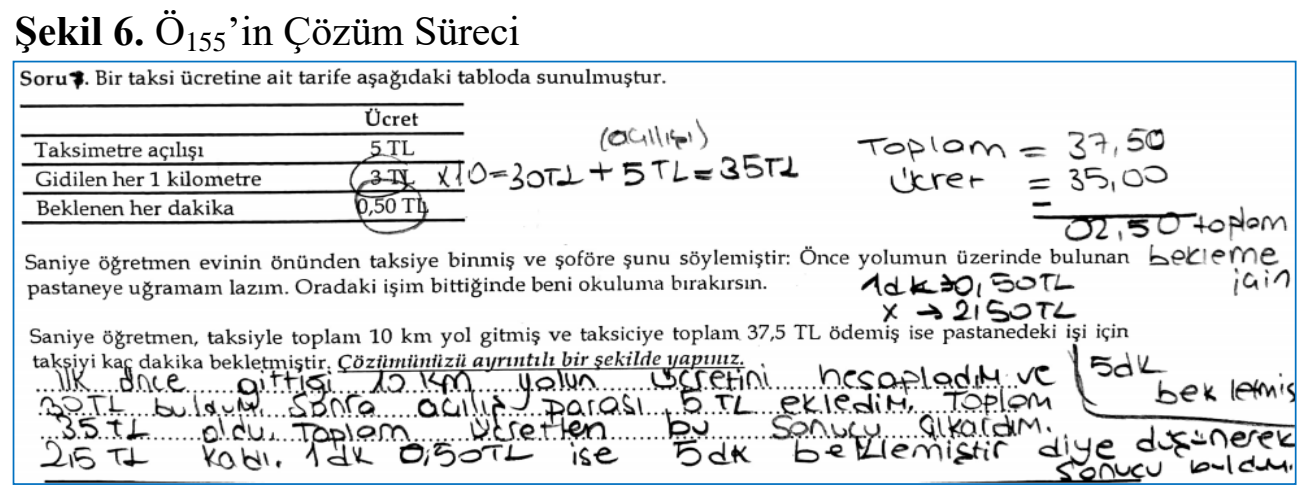

[Öğrenmenin yeteneğe bağl1 inanç toplam puanı: 18]

Matematik odaklı epistemolojik inançlar içerisinden yeteneğe bağlı öğrenme inanç puan1 düşük olan Ö$_{155}$ 'in soru çözümü incelendiğinde, çözüme uygun bir yol belirlediği görülmektedir. Bu doğrultuda çözüm için uygun bir süreci takibi etmiş ve matematiksel işlemleri etkili bir şekilde gerçekleştirmiştir. Aslında öğrenci sahip olduğu matematiksel becerileri, cebirsel düşünme becerileri ile etkili bir şekilde birleştirerek amaca uygun hareket etmiştir. Bu bakımdan öğrencinin yeteneğe bağlı inancının dışında daha baskın bir inanca sahip olduğu söylenebilir.

Şekil 7. Ö ${ }_{142}$ 'nin Çözüm Süreci

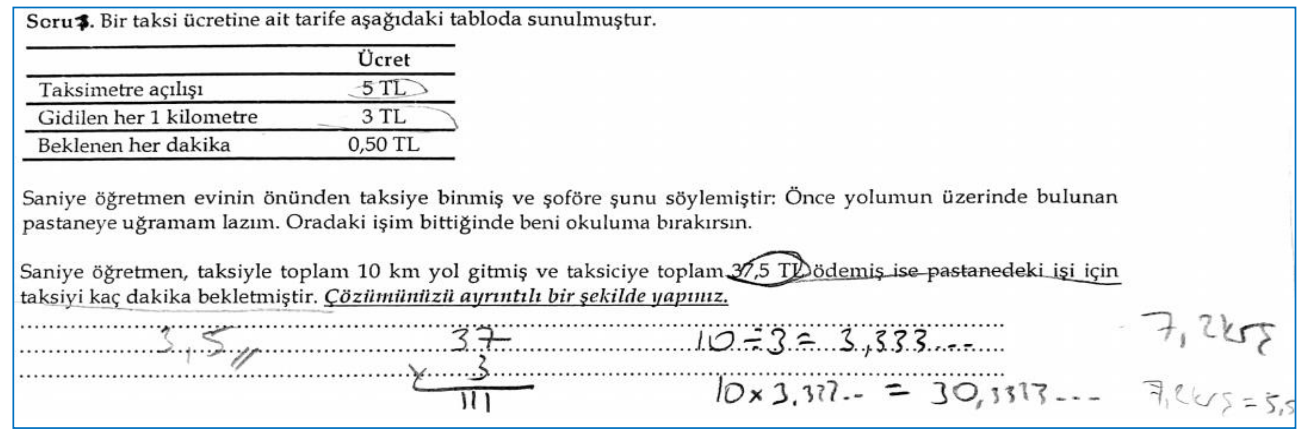

[Öğrenmenin yeteneğe bağlı inanç toplam puanı: 34]

Matematik odaklı epistemolojik inançlar içerisinden yeteneğe bağlı öğrenme inanç puanı orta düzeyin üstünde olan Ö$_{142}$ 'nin soru çözümü incelendiğinde, öncelikle çözüm için amaca uygun bir plan yapmadığı görülmektedir. Ayrıca seçmiş olduğu çözüm yolunun bir zorluğun üstesinden gelebilecek nitelikte olmadığı söylenebilir. Aslında öğrenci çözüm için bir çaba içine girmiş ancak cebirsel işlemlerdeki yeteneği çözüme ulaşmasını sınırlamaktadır. Bu bağlamda öğrencinin öğrenme yeteneğinin cebirsel bir dil için yeterli düzeyde olmadığı söylenebilir. 
Şekil 8. Ö 134 'ün Çözüm Süreci

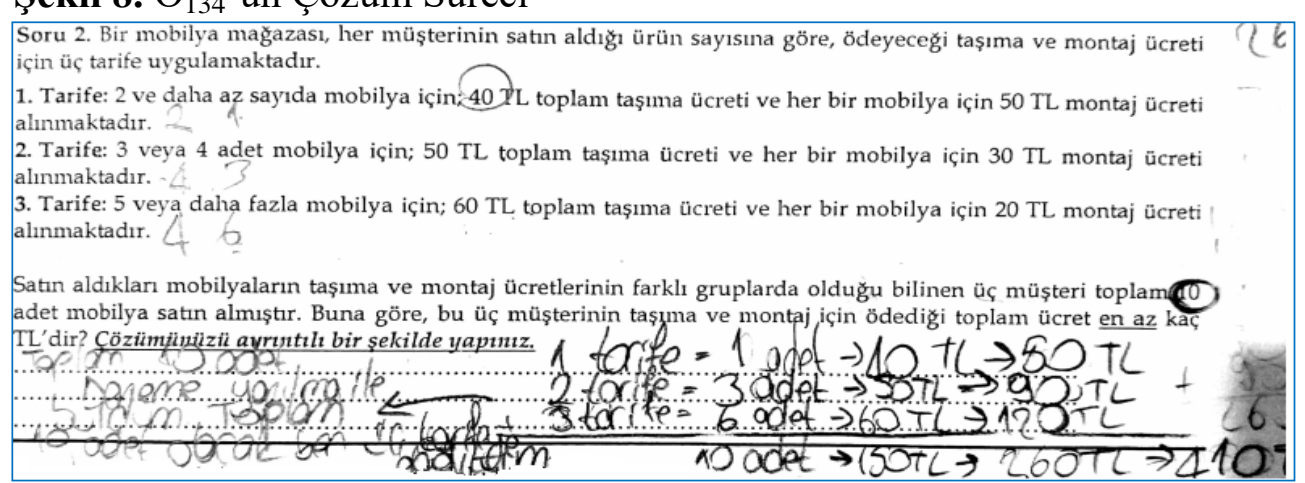

[Tek bir doğrunun var olduğuna inanç toplam puanı: 27]

Matematik odaklı epistemolojik inançlar içerisinden tek bir doğrunun var olduğu inanç puanı yüksek olan Ö$_{134}$ 'ün soru çözümü incelendiğinde, çözüme uygun bir çözüm yolu belirlediği görülmektedir. Bu durumun en güçlü göstergesi tarifelere uygun farklı çözüm alternatiflerini sınamış olmasıdır. Her bir tarife için uygun cebirselsel dili de etkili bir şekilde kullanan öğrenci, olası çözüm yolunu net bir şekilde açıklamıştır. Dikkat çeken ayrıntı ise tek bir doğrunun var olduğuna yönelik inanç puanı yüksek olan öğrencinin doğru cevaba ulaşma noktasında farklı denemelerinin olmasıdır.

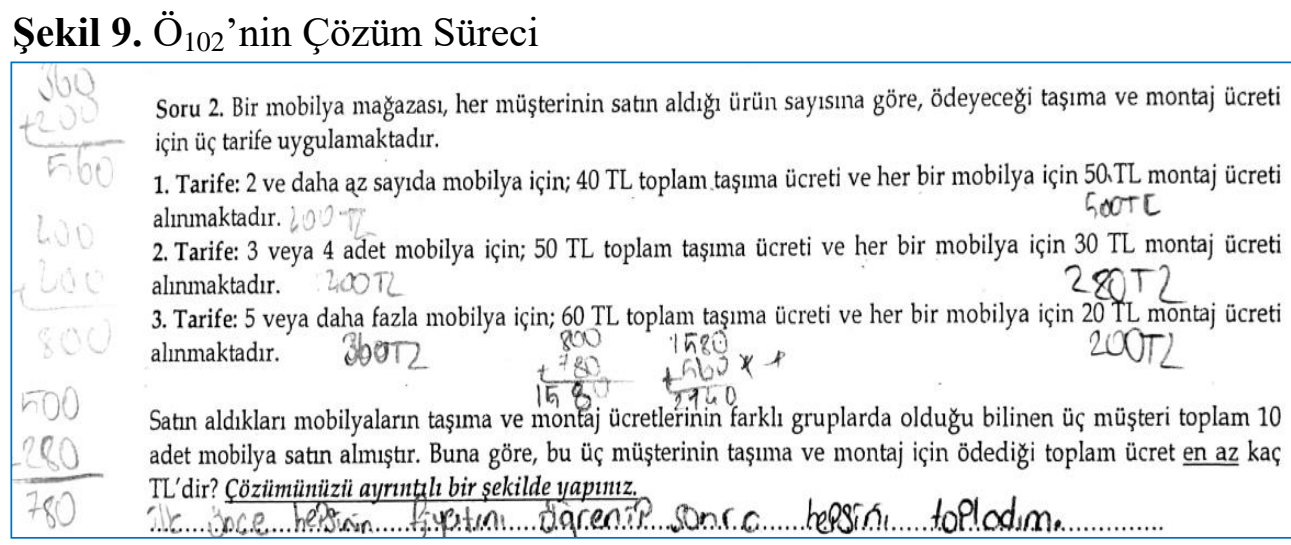

[Tek bir doğrunun var olduğuna inanç toplam puanı: 16]

Matematik odaklı epistemolojik inançlar içerisinden tek bir doğrunun var olduğu inanç puanı orta düzeyin altında olan Ö$_{102}$ 'nin soru çözümü incelendiğinde, öncelikle çözüm için amaç dışı çabaları dikkat çekmektedir. Çözüm süreci matematiksel işlemlerle sınırlı tutulmuş ve etkili bir çözüm yolu izlenememiştir. Dolayısıyla uygun bir strateji adımı takip edilmemiştir. Öğrencinin tek bir doğrunun var olduğuna yönelik inancının etkisinde hareket ettiği söylenebilir. Nitekim cebirsel işlemler yardımıyla farklı sayıda sonuca ulaşmış olsa da tek doğru inancının baskın olduğu söylenebilir.

\section{Tartışma ve Sonuç}

Araştırmada sekizinci sınıf öğrencilerinin cebirsel düşünme becerileri matematik odaklı epistemolojik inançlar bağlamında ele alınmıştır. Öncelikle öğrencilerin cebirsel düşünme becerileri ile matematik odaklı epistemolojik inançları arasındaki ilişki incelenmiştir. Daha sonra matematik odaklı epistemolojik inançlarının her bir boyutunun cebirsel düşünme becerisini anlamlı olarak yordayıp yormadığını belirlemek 
amacıyla basit doğrusal regresyon analizi uygulanmıştır. Son adımda ise matematik odaklı epistemolojik inanç alt boyutlarının birlikte cebirsel düşünme becerisini yordama gücü çoklu regresyon ile incelenmiş ve nitel verilerle çalışma sonuçları desteklenmiştir.

Araştırma bulgularına göre, sekizinci sınıf öğrencilerinin cebirsel düşünme becerileri ile çabaya bağlı inanç arasında yüksek, yeteneğe bağlı inanç ile zayıf ve tek bir doğrunun var olduğuna yönelik inanç arasında orta düzeyde pozitif yönlü anlamlı bir ilişki tespit edilmiştir. Bu bulgular ışı̆̆ında, sekizinci sınıf öğrencilerinin cebirsel düşünme becerilerinin daha çok çaba içerdiğini söyleyebiliriz. Öğrencilerin cebirsel düşünmelerinde daha çok çaba gerektiren inançlar beslemeleri onların öğrenme ortamlarındaki çabalarının desteklenmesi gerektiğine vurgu yapmaktadır. Bu bağlamda, matematik öğretmenlerinin öğrenme ortamlarını tasarlarken bu durumu dikkate almaları ve cebir konularının öğretilmesinde nitelikli rehberlik hizmeti sunması önemlidir. Ayrıca tek bir doğrunun var olduğuna yönelik inanç ile cebirsel düşünme becerisi arasındaki ilişki düşünüldüğünde, öğrencilerin cebirsel düşünmelerini desteleyecek analitik çalışmalar ile çok yönlü düşünme becerilerinin gelişimine olanak sağlayacak etkinliklere yer verilmesi yararlı olabilir. Bu sayede öğrenciler cebirsel ilişkilerin çok yönlü yapısını daha iyi tanıyarak daha sağlıklı inanç değerleri geliştirebilir. Çünkü öğrenmenin çabaya, yeteneğe ve tek bir doğrunun var olduğuna yönelik inanç faktörleri öğrencilerin ders çalışma stratejilerini önemli ölçüde etkilemektedir (Deryakulu, 2004b). Cebirsel düşünme becerileri ile matematik odaklı epistemolojik inançların boyutları arasında farklı düzeylerde ilişkinin belirlenmiş olması, Schommer (1990) tarafından dile getirilen bilgilerin birbirinden bağımsız parçalardan ve boyutlardan oluştuğu kuramsal anlayışla da örtüşmektedir. Aynı zamanda bu bulgu, öğrencilerin çoğunluğunun öğrenmenin çabaya bağlı inançlarını ön planda tuttuğu ve bu yönde daha gelişmiş epistemolojik inançlara sahip olduğu söylemleri de desteklemektedir (Öngen, 2003; Y1ldırır \& Çirkinoğlu-Şekercioğlu, 2018).

Araştırmanın bir diğer bulgusu, matematik odaklı epistemolojik inançlara ait tüm alt boyutların cebirsel düşünmeyi anlamlı bir şekilde yordamasıdır. Cebirsel düşünme üzerinde en fazla değişim çabaya bağlı inanç iken en az değişim yeteneğe bağlı inanç boyutunda olmuştur. Bu bulguya göre, öğrencilerin cebirsel düşünme becerilerinde yetenekten ziyade çabaya bağlı inancının daha baskın olduğu, tek bir doğruya yönelik inançlarını da bu çerçevede şekillendirdiği söylenebilir. Özellikle öğrencilerin tek bir doğruya yönelik inançlarının cebirsel düşünme düzeyinde yeterince gelişmemiş olması, ögrenciler için anlaşılması oldukça güç ve bir zorluk sebebi olan cebir öğrenme alanı için şaşırtıcı değildir. Çünkü öğrenciler karmaşık ve çok yönlü çözüm sürecine sahip durumlar karşısında tek bir doğrunun peşinden gitmektedir. Bu tür öğrencilerin başkaların düşüncülerini benimseme tavrı içine girmeleri de muhtemeldir (Aksan \& Sözer, 2007). Dolayısıyla bu tür inanç sistemine sahip öğrencilerin çok yönlü öğrenme ortamları ile buluşturulması aynı zamanda aktif roller üstelenecek görevlerle desteklenmesi oldukça önemlidir. Bu yüzden matematik öğretmenleri öğretim planlarını iyi organize etmeli ve soyut düşünme yapısına sahip cebir öğrenme alanına karşı öğrencilerin ön yargı oluşturmalarının önüne geçmelidir. Bu bakımdan matematik öğretmenlerinin öğrencilerin bu güçlü yönünün farkında olması ve öğrenci yeteneklerinin zamanla gelişebileceği konusunda olgunlaşmamış inançlara duyduğu ihtiyaçları bilmesi önemlidir. Çünkü öğrenmenin zaman içinde geliştiğine yönelik felsefi yaklaşım düşünüldüğünde, çabaya yönelik değerlendirmeci bir anlayışın 
öğrencilerin gelişimlerine önemli etkileri olduğu bilinmektedir (Erdamar \& Alpan, 2015; Schommer ve diğer., 1997). Aynı zamanda bu bulgu, öğrenmenin çabaya bağlı olduğuna inanan öğrencilerin bir zorluğun üstesinden gelebilecek nitelikte değerlendirici bir yaklaşımı benimsedikleri görüşünü de desteklemektedir (Aksan \& Sözer, 2007). Ancak bu sonuç, öğrencilerin problem çözümünde çaba göstermedikleri bulgusu ile çelişki göstermektedir (Yılmaz, 2007). Oysa bilginin kesinliğine, tek bir doğrunun var olduğuna ya da bilgi kaynağının otoriterliğine inanan öğrencilerin performansları da yeterli düzeyde olmaz (Qian \& Alvermann, 2000; Shommer, 1990). Elde edilen bulguların dikkat çeken ayrıntısı ise yeteneğe bağlı öğrenmenin cebirsel düşünmeyi açıklamadaki zayıflığıdır. Bu bakımdan yetenek, cebirsel düşünme becerileri için geri planda kalmış bir faktör olarak değerlendirilebilir. Çünkü öğrenciler cebirsel düşünme yeteneklerini doğuştan gelen yetenekle örtüştürmemekte bunun çabaya bağl1 olduğuna daha çok inanmaktadırlar.

Araştırmanın bir diğer bulgusu, matematik odaklı inançların birlikte, cebirsel düşünme becerisine ilişkin toplam varyansın \%65'ini açıklamış olmasıdır. Burada dikkat çeken ayrıntı ise çabaya ve tek bir doğrunun var olduğuna yönelik inançların cebirsel düşünme becerisinin anlamlı birer yordayıcıları olmalarıdır. Özellikle çabaya bağlı inancın güçlü bir yordayıcı olması öğrencilerin iyi birer cebir çözücüleri olmalarında oldukça değerlidir. Bu bakımdan matematik öğretmenlerinin öğrencilere yönelik tutumu önem arzeder. Çünkü öğrenme yaklaşımlarının etkili kullanılmasının önemi epistemolojik inançların gelişiminde tartışılmazdır (Chan, 2003). Öğrenmeyi etkileyen en önemli faktörlerin başında kişisel epistemolojik inançlar gelmektedir (Hofer, 2000). Bundan dolayı birçok çalışma bulgularıyla da raporlanmış (Ersoy \& Erbaş, 2005; OECD, 2016; TIMSS, 2016) cebir öğrenme alanının zorluğu karşısında bu inançların verimli bir şekilde kullanılması gerekir. Özellikle matematik öğretmenlerinin epistemoloji kavramını iyi bilmesi, öğrencilerinin sahip olduğu epistemolojik inançlarının yönünü kestirebilmesi ve her şeyden önemlisi kendi inanç değerlerini öğrenme ortamlarına olumlu şekilde yansıtabilmeleri gerekir. Soyut yapısından dolayı birçok öğrencinin güçlük çektiği konuların başında gelen cebirin daha nitelikli öğretimi konusunda epistemolojik inançların varlığının farkında olmak önemli bir basamak olarak görülebilir. Bu sayede öğreticiler, öğrencilerinin çabalarını destekleyici öğrenme ortamı tasarlamada daha organize bir yolu seçme imkânı elde edebilir. Özellikle öğrencilerin öğrenmeye yönelik inançlarını belirlemek, onların cebir öğrenimine bakış açılarını geliştirme yönünde destekler sunabilir. Diğer yandan tek bir doğrunun var olduğuna yönelik inancın cebirsel düşünme becerisi üzerindeki etkisi düşünüldüğünde, bu duruma sebep olabilecek birçok faktör grubundan söz etmek mümkündür. Ancak temel nedenler arasında uygulanan öğretim yöntem ve tekniklerin yer aldığı söylenebilir (Deryakulu, 2004b). Çünkü öğrenme yaşantıların zenginliği öğrencilerin daha gelişmiş inançlara sahip olmasına aracılık etmektedir. Nitekim gelişmiş inançlara sahip bireyler, problemi çözmek için tek bir çözüm yolu aramak yerine farklı seçenekleri araştırır (Erdamar \& Alpan, 2015; Hofer \& Pintrich, 1997). Öğrencilerin cebir sorularının çözümünde tek bir doğrunun var olduğuna yönelik benimsemiş olduğu inançların altında yatan temel nedenlerden birisi de geleneksel öğretim anlayışına bağlı uygulamalar ile tek bir doğru cevaba odaklanmış cebirsel düşünme biçimlerinden kaynaklanmasıdır. Elde edilen bulgular öğrencilerin cebirsel düşünmelerini yordamada epistemolojik inançların önemli bir rolü olduğunu göstermektedir. Nitekim elde edilen 
sonuçlar, alanyazındaki birtakım çalışma sonuçlarını da desteklemektedir (Aksan \& Sözer, 2007; Haciömeroğlu, 2011).

Araştırmanın nitel verileri değerlendirildiğinde, çabaya bağlı inanç puanı yüksek olan öğrencilerin daha organize cevaplar verdiği gözlemlenmiştir. Bu özelliğe sahip öğrencilerin cevap kâğıtlarında dikkat çeken en önemli ayrıntı, çoğunluğunda çözüm için amaca uygun planlar yapmış olmalarıdır. Ayrıca çözüme yönelik uygun denklem oluşturma, zorluğun üstesinden gelebilecek mantıklı çıkarımlar yapma, cebirsel dili etkili kullanma ve etkili bir çözüm yolunu seçme diğer ayrıntılar arasında gösterilebilir. $\mathrm{Bu}$ öğrencilerin cebirsel düşünme yeteneklerinde değerlendirici yaklaşıma bağlı kaldıkları söylenebilir. Nitekim öğrenmenin çabaya bağlı olduğuna inanan öğrencilerin cebir problemlerinin çözümünde değerlendiren olması arzu edilen sonuçtur. Çünkü değerlendiren öğrenciler, karşılaştıkları sorunları çözmek için farklı seçenekleri dikkate almakta ve acele karar vermekten kaçınmaktadır (Erdamar \& Alpan, 2015). Diğer yandan öğrenmenin yeteneğe bağlı olduğuna yönelik inanç puanı orta düzeyin üstündeki öğrencilerin genelinde amaca uygun bir planın olmadığı göze çarpmaktadır. Öğrenciler, cebire bakış açılarını yetenekle ilişkilendirmemektedir. Bu yüzden cebir için arzu edilen öğrenmelerin gerçekleştirilmesinde çabaya bağlı inanç değerinin yanında yeteneğinin de ön planda tutulduğu bir anlayışın oluşturulması gerekir. Tek bir doğrunun var olduğuna yönelik öğrencilerin cevap kâğıtları irdelendiğinde, farklı bir döngüden söz etmek mümkündür. Örneğin tek bir doğru inancı yüksek olan öğrencilerden beklenen durum, tek bir doğru cevap üzerinde durması ve bu cevaba ulaşma noktasında birtakım işlemlerle herhangi bir cevabı doğru olarak kabul ederek hareket etmesidir. Ancak buradaki paradoks tek bir doğrunun varlığına inanan öğrencinin çözüm için uygun plan dâhilinde hareket etmesidir. Üstelik cebirsel dili de etkili kullanmış olmalarıdır. Bu durumu, sorunun yapısı ile ilişkilendirebiliriz. Aslında öğrenci sorunun olası çözüm yollarının farkında ve tek bir doğru cevaba ulaşma için çaba harcamaktadır. Oysa tek bir doğrunun varlığına ilişkin inançtan uzaklaşan öğrenciler, problemin çözüm sürecinde ortaya çıkan sonuç ile olması gerektiğini düşündükleri sonucu karşılaştırma tutumunu daha fazla sergilemektedirler (Aksan \& Sözer, 2007; Schommer, 1993).

Sonuç olarak, öğrenci davranışları üzerindeki etkisi birçok çalışmaya ve kuramsal açıklamaya konu olan epistemolojik inançların cebirsel düşünme becerisindeki etkisinin tartışılması araştırmaya değer konu olarak karşımıza çıkmaktadır. Bilindiği üzere ortaokul öğrencileri genellikle, öğretmenlerinin davranışlarına ve tutumlarına karşı oldukça hassastır. Özellikle birçok öğrenci anlamlandırmakta zorluk çektiği cebirsel düşünme ile karşı karşıya kaldığında öğretmenlerin onlara olan davranışları bu süreçte daha bir önem arz etmektedir. Dolayısıyla öğretmenlerin öğrencilerin inançları hakkında bilgi sahibi olması onların cebir ile mücadele etmelerinde oldukça önemlidir. Tüm bu anlatımlara ek olarak, çalışmanın birtakım sınırlılıkları da bulunmaktadır. Örneğin çalışma grubu sadece sekizinci sınıf öğrencilerinden oluşmaktadır. Bir diğer sınırlılık ise çalışmada gönüllü öğrencilere yer verilmiş olmasıdır. Çalışmada yer almayan ya da almak istemeyen öğrencilerin cebirsel düşünme becerileri ile epistemolojik inançları arasındaki ilişkinin bilinmesi önemlidir. Çünkü çalışmada olmayan öğrencilerin epistemolojik inançları ile cebirsel düşünme becerileri farklılık gösterebilir. 


\section{Öneriler}

$\checkmark$ Eğitimde kritik bir rol üstlenen epistemolojik inançlar, cebir öğrenme alanında etkili bir öğrenme ortamının oluşturulmasında önemli bir firsat aracıdır. Bu bakımdan öğretim faaliyetlerinin başında öğrencilerin epistemolojik inançlarının bilinmesi konuların anlaşılmasına daha fazla yarar sağlayabilir.

$\checkmark$ Öğrenme ortamlarındaki en önemli değişkenler hiç şüphesiz öğrenenlerdir. Onların değer yargıları ve öğrenmeye ilişkin olumlu inançları bir konunun daha iyi öğrenilmesi açısından etkilidir. Bu bakımdan öğrenme çevrelerinin düzenlenmesinde öğrencilerin inançları göz önünde bulundurulabilir.

$\checkmark$ Özellikle öğrencilerin öğrenmenin çabaya bağlı olduğuna yönelik inançlarının köreltilmemesi amacıyla uygun ders planları oluşturulabilir. Cebir öğrenme alanını içeren kazanımlar bu çerçevede şekillendirilebilir.

$\checkmark$ Çalışma sekizinci sınıf öğrencileri ile sınırlı tutulmuştur. Cebir konularının matematik öğretim proramında yerini aldığı sınıflardan başlanarak daha geniş ölçekte çalışmalar yapılabilir.

$\checkmark$ Tek bir sınıf düzeyi veya farklı sınıf düzeylerini de içine alan boylamsal çalışmalar yapılarak daha derinlemesine bilgi edinilmeye çalışılabilir. 


\section{Summary}

Purpose and Significance: Algebra learning is one of the indispensable elements of today's information society. It has a strong dynamic structure, unique features, a function that feeds many fields, and a history of about 4000 years. Algebra has become a challenging area for students since they feel their presence in today's mathematics teaching curriculum. With this being the case for many reasons, the use of letters for unknown numbers and the presence of variables are among the main facts (Chaurasia, 2016). Apart from this, misunderstanding of algebraic concepts (Dede \& Argün, 2003), difficulties in solving equations (Van Amerom, 2003), feeling problems in terms of equality and variables (Ersoy \& Erbaş, 2005), difficulties in arithmetical transition (Akkan \& Baki, 2016) and misinterpretation of letters (Kieran, 1992; MacGregor \& Stacey, 1997) are among other reasons. Despite the considerable improvements in the field, it is seen that there is not enough progress recorded ineffective algebra teaching. The strongest proof of this situation is evident in reports that international organizations have published (OECD, 2016; TIMSS, 2016). For this reason, researching the variables that affect students' algebra performances is an important issue. One of the most important aspects of education policies is the belief values of the students. Over the past decade, there has been a growing interest in the beliefs and epistemological developments of individuals, especially by educators. The most important reasons for this situation are the role of individual factors in success (Schommer, 1990). Therefore, the debate on algebraic thinking, which affects individuals' decisions and behaviors (Hofer \& Pintrich, 1997), is antagonistic as a matter of research. The main purpose of the study is to try to explain the eighth-grade students' algebraic thinking skills in the context of mathematics-oriented epistemological beliefs.

Methods: In the research, the relational research design was used in the research because it was aimed to determine the relationship between mathematics-oriented epistemological beliefs and algebraic thinking skills. The study group of the study consists of 162 students in the eighth-grade of a state middle school in İzmir city center in the academic year of 2017-2018. The creation of the study group is based on the appropriate sampling method. This method works on a suitable example that is not arbitrary for being selected from easily accessible and implementable units.

Results: According to research findings, the strongest correlation between algebraic thinking skills and mathematics-oriented epistemological beliefs of eighth-grade students was the beliefs in an effort, while the lowest correlation was between talent beliefs. In addition to this, a significant positive correlation was found at the high level with the beliefs related to effort, weak level with the beliefs related to the talent and moderate level with the beliefs related to a single truth. On the other hand, all the variables of mathematics-oriented epistemological beliefs are reasonably predicting algebraic thinking. The greatest change in algebraic thinking is the belief that it depends on the effort, but the least change is the belief that it depends on the talent. Mathematics-oriented beliefs together account for $65 \%$ of the total variance of algebraic thinking skills. On the other hand, beliefs related to effort and single truths are significant predictors of algebraic thinking. When the qualitative data obtained from the 
research is evaluated, the students with high belief score related to the experiment give more organized answers.

Discussion and Conclusions: In this light of the finds, we can say that algebraic thinking skills of eighth-grade students involve more effort. The beliefs that require more effort in the algebraic thinking of the students emphasize that their efforts in their learning environments should be supported. In this context, it is important for mathematics teachers to consider this situation when designing learning environments and to provide qualified guidance services in the teaching of algebraic subjects. In addition, when considering the relationship between belief in the existence of a single truth and algebraic thinking skills, it may be useful to include analytical studies that will support students in algebraic thinking and activities that will enable the development of multifaceted thinking skills. In this way, students can better understand the multifaceted nature of algebraic relations and develop a better sense of belief. Because of the belief that effort, talent and the single truth have a significant effect on the learning strategies of the students (Deryakulu, 2004b). In particular, mathematics teachers need to be aware of the epistemological concept, to predict the direction of their epistemological beliefs, and most importantly to reflect their beliefs values in a positive way. Being aware of the existence of epistemological beliefs in the more qualified teaching of algebra which many learners have difficulty due to their abstract structure can be seen as an important step. At this point, tutors may be able to choose a more organized way of designing the learning environment that supports their students' efforts. In particular, identifying students' beliefs about learning can provide support for developing their views on algebra learning. As a result, it is very important for teachers to have knowledge about the beliefs of their students in their fight against algebra. Epistemological beliefs, which play a critical role in the educational process, represent an important opportunity for creating an effective learning understanding in the field of algebra learning. In this regard, learning of epistemological beliefs of students at the beginning of teaching activities can provide more benefits in understanding the issues. 


\section{Kaynakça}

Akkan, Y., \& Baki, A. (2016). Ortaokul öğrencilerinin aritmetikten cebire geçiş süreçlerinin incelenmesi: Sembollerin kullanımı ve harflerin anlamı. Bayburt Eğitim Fakültesi Dergisi, 11(2), 270-305.

Aksan, N., \& Sözer, M. A. (2007). Üniversite öğrencilerinin epistemolojik inançları ile problem çözme becerileri arasındaki ilişkiler. Ahi Evran Üniversitesi Kırşehir Ĕ̈itim Fakültesi Dergisi, 8(1), 31-50.

Aydemir, N., Aydemir, M., \& Boz, Y. (2013). Lise öğrencilerinin epistemolojik inançları. Kastamonu Ĕ̈itim Dergisi, 21(4), 1305-1316.

Büyüköztürk, Ş. (2017). Sosyal bilimler için veri analizi el kitabı (23. baskı). Ankara: PegemA Yayıncilık.

Büyüköztürk, Ş., Çakmak, E. K., Akgün, Ö. E., Karadeniz, Ş., \& Demirel, F. (2014). Bilimsel araştırma yöntemleri (17. baskı). Ankara: Pegem Yayınları.

Can, A. (2016). SPSS ile bilimsel araştırma sürecinde nicel veri analizi (4. baskı). Ankara: Pegem Akademi.

Carpenter, T. P., \& Levi, L. (2000). Developing conceptions of algebraic reasoning in the primary grades. Research Report Madison, WI: National Center for Improving Student Learning and Achievement in Mathematics and Science. https://files.eric.ed.gov/fulltext/ED470471.pdf (Erişim Tarihi: 03.02.2018).

Chan, K. W. (2003). Hong Kong teacher education students' epistemolojik beliefs and approaches to learning. Research in Education, 69(1), 36-50.

Chaurasia, P. (2016). Algebraic reasoning at elementary level: Filling the gaps between arithmetic and algebra. International Journal of Scientific Research, 5(10), 241242.

Cuoco, A., Goldenberg, P., \& Mark, J. (1996). Habits of mind: An organizing principle for mathematics curriculum. Journal of Mathematical Behavior, 15, 375-402.

Çelik, D. (2007). Öğretmen adaylarının cebirsel düşünme becerilerinin analitik incelenmesi (Yayımlanmamış Doktora Tezi). Karadeniz Teknik Üniversitesi, Fen Bilimleri Enstitüsü, Trabzon.

Çokluk, Ö., Şekercioğlu, G., \& Büyüköztürk, Ş. (2014). Sosyal bilimler için çok değişkenli istatistik: SPSS ve Lisrel uygulamaları (3. baskı). Ankara: Pegem Akademi Yayıncılık.

Çüçen, A. K. (2013). Bilim felsefisine giriş (2. baskı). Ankara: Sentez Yayınları.

Dede, Y. (2004). Değişken kavramı ve öğrenimindeki zorluklarının belirlenmesi. Kuram ve Uygulamada Ĕ̈itim Bilimleri, 4(1), 25-56.

Dede, Y., \& Argün, Z. (2003). Cebir, öğrencilere niçin zor gelmektedir?. Hacettepe Üniversitesi Eğitim Fakültesi Dergisi, 24, 180-185.

Deryakulu, D., \& Büyüköztürk, Ş. (2002). Epistemolojik inanç ölçeğinin geçerlik ve güvenirlik çalışması. Eğitim Araştırmaları Dergisi, 2(8), 111-125.

Deryakulu, D. (2004a). Epistemolojik inançlar. Yıldız Kuzgun \& Deniz Deryakulu (Ed.), Eğitimde bireysel farklılıklar (pp. 259-288). Ankara: Nobel Yayınevi. 
Deryakulu, D. (2004b). Üniversite öğrencilerinin öğrenme ve ders çalışma stratejileri ile epistemolojik inançları arasındaki ilişki. Kuram ve Uygulamada Eğitim Yönetimi, $38,230-249$.

Driscoll, M. (1999). Fostering algebraic thinking: A guide for teachers grades 6-10. Portsmouth, NH: Heinemann.

Erbaş, A. K., Çetinkaya, B., \& Ersoy, Y. (2009). Öğrencilerin basit doğrusal denklemlerin çözümünde karşılaştıkları güçlükler ve kavram yanılgıları. Eğitim ve Bilim, 34(152), 44-59.

Erdamar, G., \& Alpan, G. (2015). Öğretmen adaylarının epistemolojik inançlarının ve problem çözme yeteneklerinin gelişimi: Boylamsal bir çalışma. Türk Eğitim Bilimleri Dergisi, 13(2), 77-91.

Ersoy, Y., \& Erbaş, K. (2005). Kassel projesi cebir testinde bir grup Türk öğrencinin genel başarısı ve öğrenme güçlükleri. İlköğretim Online, 4(1), 18-39.

Fraenkel, J. R., \& Wallen, M.E. (2009). How to design and evaluate research in education ( $7^{\text {th }}$ ed.). New York: MacGraw-Hill.

Hacıömeroğlu, G. (2011). Sınıf öğretmeni adaylarının matematiksel problem çözmeye ilişkin inançlarını yordamada epistemolojik inançlarının incelenmesi. Buca Eğitim Fakültesi Dergisi, 30, 206-220.

Hofer, B. K. (2000). Dimensionality and disciplinary differences in personal epistemology. Contemporary Educational Psychology, 25(4), 378-405.

Hofer, B. K., \& Pintrich, P. R. (1997). The development of epistemological theories: Beliefs about knowledge and knowing and their relation to learning. Review of Educational Research, 67(1), 88-140.

İlhan, M., \& Çetin, B. (2013). Matematik odaklı epistemolojik inanç ölçeği (MOEİÖ): Geçerlik ve güvenirlik çalışması. Kuramsal Eğitimbilim Dergisi, 6(3), 359-388.

Kaput, J. J. (1998). Transforming algebra from an engine of inequity to an engine of mathematical power by "algebrafying" the K-12 curriculum. In S. Fennel (Ed.), The nature and role of algebra in the $K-14$ curriculum: Proceedings of the national symposium (pp. 25-26). Washington, DC: National Research Council, National Academy Press.

Kaput, J. J. (2002). Research on the development of algebraic reasoning in the context of elementary mathematics: A brief historical overview. In D. S. Mewborn, P. Sztajn, D. Y. White, H. G. Wiegel, R. L. Bryant, \& K. Nooney (Eds.), Proceedings of the twenty-fourth annual meeting of the international group for the psychology of mathematics education (pp. 120-122). Columbus, OH: ERIC.

Kaput, J. J. (2008). What is algebra? What is algebraic reasoning? In J. J. Kaput, D. W. Carraher, \& M. L. Blanton (Eds.), Algebra in the early grades (pp. 5-17). New York: Taylor \& Francis Group.

Karasar, N. (2013). Bilimsel araştırma yöntemi (25. baskl). Ankara: Nobel Yayın Dağıtım.

Kaya, D. (2015). Çoklu temsil temelli öğretimin öğrencilerin cebirsel muhakeme becerilerine, cebirsel düşünme düzeylerine ve matematiğe yönelik tutumlarına etkisi üzerine bir inceleme (Yayımlanmamış Doktora Tezi). Dokuz Eylül Üniversitesi, Eğitim Bilimleri Enstitüsü, İzmir. 
Kieran, C. (1992). The learning and teaching of school algebra. In D. Grouws (Ed.), Handbook of research on mathematics teaching and learning (pp. 3-33). New York: Macmillan.

Kieran, C., \& Chalouh, L. (1993). Prealgebra: The transition from arithmetic to algebra. In D. T. Owens (Ed.), Research ideas for the classroom: Middle grades mathematics (pp. 179-198). New York: Macmillan.

Lew, H. C. (2004). Developing algebraic thinking in early grades: Case study of Korean elementary school mathematics. The Mathematics Educator, 8(1), 88-106.

Macgregor, M., \& Stacey, K. (1997). Students' understanding of algebraic notation: 1115. Educational Studies in Mathematics, 33, 1-19.

Marzano, R. J. (2000). Transforming classroom grading. Alexandria, VA: Association for Supervision and Curriculum Development.

Miles, M, B., \& Huberman, A. M. (1994). Qualitative data analysis: An expanded sourcebook $\left(2^{\text {nd }} \mathrm{ed}\right)$. Thousand Oaks, California: Sage Publications.

Milli Eğitim Bakanlığı [MEB] (2018). Matematik dersi öğretim programı (İlkokul ve ortaokul 1,2,3,4,5,6,7 ve 8. siniflar). Ankara. http://mufredat.meb.gov.tr/ProgramDetay.aspx?PID=329 (Erişim Tarihi: 25.04.2018).

National Assessment of Educational Progress [NAEP] (2015). The nation's report card: Mathematics and reading assessments. http://nces.ed.gov/nationsreportcard/ (Erişim Tarihi: 03.03.2018).

National Council of Teachers of Mathematics [NCTM] (2006). Principles and standards for school mathematics. Reston, VA: National Council of Teacher of Mathematics. http://www.nctm.org/ (Erişim Tarihi: 11.01.2018).

National Council of Teachers of Mathematics [NCTM] (2014). Principles to actions: Ensuring mathematical success for all. Reston, VA: NCTM.

Organisation for Economic Co-operation and Development [OECD] (2016). PISA 2015 results in focus. OECD, Paris. http://www.oecd.org/pis (Erişim Tarihi: 03.02.2018).

Öngen, D. (2003). Epistemolojik inançlar ile problem çözme stratejileri arasındaki ilişkiler: Eğitim fakültesi öğrencileri üzerine bir çalışma. Eğitim Araştırmaları Dergisi, 3(13), 155-162.

Özkan-Hıdıroğlu, Y., \& Hıdıroğlu, Ç. N. (2016). Matematik öğretmenlerinin matematiksel modellemedeki yaklaşımlarını açıklamada epistemolojik inançlarının incelenmesi. Eğitimde Kuram ve Uygulama, 12(1), 17-40.

Qian, G., \& Alvermann, D. (2000). Relationship between epistemological beliefs and conceptual change learning. Reading \& Writing Quarterly, 16(1), 59-74.

Ralston, N. C. (2013). The development and validation of a diagnostic assessment of algebraic thinking skills for students in the elementary grades (Unpublished doctoral dissertation). University of Washington, Educational Psychology, (UMI Number: 3588844).

Romberg, T., \& M. Spence (1995). Some thoughts on algebra for the evolving work force. In C. Lacampagne, W. Blair, and J. Kaput (Eds.), The algebra initiative colloquium (vol. 2), 177-192. Washington, DC: U. S. Department of Education. 
Russell, S. (1999). Mathematical reasoning in the elementary grades. In L. V. Stiff and F. R. Curcio (Eds.), Developing mathematical reasoning in grades $K-12$, (pp. 1-12), Reston, VA: NCTM.

Schommer, M. (1990). Effects of beliefs about the nature of knowledge on comprehension. Journal of Educational Psychology, 82(3), 498-504.

Schommer, M. (1993). Epistemological development and academic performance among secondary students. Journal of Educational Psychology, 85(3), 406-411.

Schommer, M. (1998). The influence of age and education on epistemological beliefs. British Journal of Educational Psychology, 68(4), 551-562.

Schommer, M., Calvert, C., Gariglietti, G., \& Bajaj, A. (1997). The development of epistemological beliefs among secondary students: A longitudinal study. Journal of Educational Psychology, 89(1), 37-40.

Schommer, M., \& Dunnell, P. (1997). Epistemological beliefs of gifted high school students. Roeper Review, 19(3), 153-156.

Schommer-Aikins, M., Duell, O. K., \& Hutter, R. (2005). Epistemological beliefs, mathematical problem-solving beliefs, and academic performance of middle school students. The Elementary School Journal, 105(3), 289-304.

Slavit, D. (1999). The role of operation sense in transitions from arithmetic to algebraic thought. Educational Studies in Mathematics, 37, 251-274.

Stacey, K., \& MacGregor, M. (1999). Learning the algebraic method of solving problems. The Journal of Mathematical Behavior, 18(2), 149-167.

Tabachnick, B. G., \& Fidell, L. S. (2013). Using multivariate statistics (6 ${ }^{\text {th }}$ ed.) Boston: Pearson.

Tavşanc1l, E., \& Aslan, E. (2001). İçerik analizi ve uygulama örnekleri. İstanbul: Epsilon Yayınları.

TEDMEM. (2018). 2017 eğitim değerlendirme raporu (TEDMEM değerlendirme dizisi 4). Ankara: Türk Eğitim Derneği Yayınları.

Tezci, E., \& Uysal, A. (2004). Eğitim teknolojisinin gelişmesinde epistemolojik yaklaşımların etkisi. The Turkish Online Journal of Educational Technology, 3(2), 158-164.

Trends in International Mathematics and Science Study (TIMSS) (2016). Highlights from TIMSS and TIMSS advanced 2015. https://nces.ed.gov/timss/timss2015/ (Erişim Tarihi: 18.02.2018).

Usiskin, Z. (1995). Thoughts preceding the algebra colloquium. In C. Lacampagne, W. Blair, and J. Kaput (Eds.), The algebra initiative colloquium (vol. 2), 87-92. Washington, DC: U. S. Department of Education.

Van Amerom, B. A. (2003). Focusing on informal strategies when linking arithmetic to early algebra. Educational Studies in Mathematics, 54(1), 63-75.

Vance, J. H. (1998). Number operations from an algebraic perspective. Teaching Children Mathematics, 4, 282-285.

Yıldırır, H. E., \& Çirkinoğlu-Şekercioğlu, A. G. (2018). An analysis of teacher candidates' epistemological beliefs: A qualitative study. Pegem Ĕgitim ve Ögrretim Dergisi, 8(1), 173-210. 
Yılmaz, K. (2007). Öğrencilerin epistemolojik ve matematik problemi çözümlerine yönelik inançlarının problem çözme sürecine etkisinin araştırılması (Yayımlanmamış Yüksek Lisans Tezi). Marmara Üniversitesi, Eğitim Bilimleri Enstitüsü, İstanbul. 